\title{
Analysis of Environmental Health Risk of So2, No2, Nh3, and Dust Exposure In Sentra Industri Surabaya, Gresik And Sidoarjo City
}

\author{
Bintang Aji Pangestu*, R. Azizah, Rica Naudita Krisna Setioningrum \\ Faculty of Public Health, Airlangga University, Campus C Surabaya, Indonesia \\ * bintang.aji.pangestu-2016@fkm.unair.ac.id
}

\begin{abstract}
Every process of industrial activity generates potential waste as air pollutants. Air pollution in the long term will result in various health problems for workers in the industrial area. Air pollution needs to be analyzed to estimate the magnitude of the risk posed. The purpose of this study was to investigate environmental health risks in exposure to SO2, NO2, NH3, and dust gases for workers in Surabaya, Gresik, and Sidoarjo in 2020. The method of this research is by collecting secondary data, namely 10 locations of industrial centers in the City of Surabaya, Gresik, and Sidoarjo. Secondary data was obtained from laboratory examinations, BBTKLPP Surabaya, and literature from several sources to support the available data. The secondary data collected was calculated using the Environmental Health Risk Analysis (ARKL) method by finding the concentration value, the amount of intake, and the characteristics of the maximum and minimum health risks of each chemical agent in the air parameters in the work environment. The research results show that the concentrations of exposure to $\mathrm{SO} 2, \mathrm{NO} 2, \mathrm{NH} 3$, and dust in the safe category at the industrial centers of Surabaya, Gresik, and Sidoarjo for workers.
\end{abstract}

Keywords: Air, Pollution, Environmental Health Risk Analysis, Workers 


\section{STRADA Jurnal Ilmiah Kesehatan}

DOI: $10.30994 /$ sjik.v9i2.350

ISSN: 2252-3847 (print); 2614-350X (online)

Vol.9 No.2 November 2020 Page.1346-1352

\section{BACKGROUND}

East Java has the potential for land that is used for industrial activities. Based on data from the East Java Central Statistics Agency (BPS) in 2019, manufacturing production increased by 7.34 percent. Surabaya, Gresik, and Sidoarjo are industrial centers in East Java. Based on the 2015 BPS data from the Surabaya region, Sidoarjo City has 238 manufacturing units. There were 967 industrial business units in Surabaya, making it the most industrial area in East Java. From these data, it can be concluded that the three cities, namely Surabaya, Gresik, and Sidoarjo, are industrial centers in East Java.

Waste generated from industrial activities in the process has the potential as an air pollutant, including SO2 (Sulfur Dioxide), CO (Carbon monoxide), NO2 (Nitrogen dioxide) gas, PM10 dust, H2S (Hydrogen Sulfide) gas, NH3 gas (NH3 gas) ammonia), and HC (Hydrocarbon) gas (Mukono, 2008). Air pollutants produced by industrial activities have been regulated following predetermined threshold values if exceeding the predetermined values can cause health problems for workers and people living in the industrial area.

Air pollution from the long term will accumulate and will have a negative impact on health. The negative impact caused by air pollutants can be estimated to be a significant health risk. To assess the magnitude of health risks that arise, we need an Environmental Health Risk Analysis (ARKL). This approach is used to examine the potential significance of risk, which begins by describing known environmental problems and involves determining health risks to humans. ARKL can be used to estimate the amount of risk received in the future. Therefore we need an Environmental Health Risk Analysis by looking at the minimum and maximum concentration values of each chemical parameter in ambient air. This is done to determine the potential risk factors or health impacts caused by the community's body from the concentration of chemicals in ambient air from the value of the minimum concentration to the maximum concentration. Looking at the minimum and maximum concentration values for each compound, this is because the minimum and maximum values are a range to estimate the impact that occurs from the minimum to the maximum concentration values for each chemical parameter in ambient air. This needs to be done to know the ambient air quality in the industrial center of East Java to seek risk management to control impacts, monitor, and manage environmental health.

\section{METHODS}

This research was conducted by collecting secondary data from 10 locations of ambient air in the company in Surabaya, Gresik, and Sidoarjo. This secondary data collection was obtained from the BBTKLPP Surabaya profile in general, laboratory examination results, and various kinds of BBTKLPP laboratory examination parameters along with SNI and related regulations and literature from several sources to support the available data. Secondary data that have been obtained will be calculated, including the value of concentration, the amount of intake, and characteristics of maximum and minimum health risks. Also given directions, briefing, and material for subsequent data retrieval.

\section{RESULTS}

\section{Hazard identification}

In this stage, it is used to determine the risk agent's type, nature, and ability of an agent that can cause adverse effects to the organism, system, or population. Ten points taken in 2020 showed four chemicals that are considered to pose health risks if consumed within a specified period. These chemical agents are: 


\section{STRADA Jurnal Ilmiah Kesehatan}

DOI: $10.30994 /$ sjik.v9i2.350

ISSN: 2252-3847 (print); 2614-350X (online)

Vol.9 No.2 November 2020 Page.1346-1352

1. Sulfur Dioxide $\left(\mathrm{SO}_{2}\right)$

$\mathrm{SO} 2$ is an air pollutant that is colorless but has a pungent odor in the form of pollutants that come from burning or using fossil fuel energy such as oil, gas, and coal. The source of the pollution comes from the production process, solid waste, transportation, coal fuel, fuel oil, power plants, copper smelting, and incinerators, while in the free Sulfur Dioxide is released into the air from volcanic eruptions.

2. Nitrogen Dioxide $\left(\mathrm{NO}_{2}\right)$

Nitrogen dioxide $\left(\mathrm{NO}_{2}\right)$ is in the atmosphere and is the gas most widely known as an air pollutant. The process of reaction between nitrogen and oxygen in the air will form $\mathrm{NO}_{2}$. This gas is non-flammable, reddish-brown, and has a strong odor. $\mathrm{NO}_{2}$ gas comes from motor vehicle fumes and burning fossil fuels in the form of coal, oil, and natural gas. $\mathrm{NO}_{2}$ gas causes an irritating effect on the lungs, thereby causing pulmonary edema after exposure to $\mathrm{NO}_{2}$ gas for 24-72 hours.

3. Ammonia $\left(\mathrm{NH}_{3}\right)$

Ammonia gas is a colorless, odorless gas produced from the activity of spoilage bacteria and the chemical fertilizer industry. Ammonia gas emissions cause health problems in the respiratory tract, irritation of the mucous membranes of the eyes, dizziness, and other health problems. Ammonia concentrations that are quite low in the air produce a rapid effect on the eyes, nose, and throat irritation, coughing, and bronchial constriction. (ATSDR, 2004)

4. Dust

The natural source of dust particulates comes from soil exposed to wind gusts. Sources of dust in the vicinity of the industrial area can come from land, air, vehicle traffic density, and the effectiveness of the engine and humans(EPA, 2018).

Table 1. Test Results of Air Pollution in the Industrial Center Environment in East Java.

\begin{tabular}{|c|c|c|c|c|}
\hline \multirow[t]{2}{*}{$\mathrm{C}$} & \multicolumn{4}{|c|}{ Parameter Results } \\
\hline & $\mathrm{SO}_{2}$ & $\mathrm{NO}_{2}$ & $\mathrm{NH}_{3}$ & Dust \\
\hline \multicolumn{5}{|c|}{ Surabaya } \\
\hline Cmin & 0,0003 & 0.0021 & 0.0017 & 0.009 \\
\hline Cmax & 0.0773 & 0.0314 & 0.1344 & .205 \\
\hline \multicolumn{5}{|c|}{ Gresik } \\
\hline $\mathrm{Cmin}$ & 0.0013 & 0.0019 & 0.0063 & 0.023 \\
\hline $\mathrm{Cmax}$ & 0.0302 & 0.0260 & .7781 & .138 \\
\hline \multicolumn{5}{|c|}{ Sidoarjo } \\
\hline Cmin & 0.0014 & 0.0022 & 0.0180 & 0.026 \\
\hline $\mathrm{Cmax}$ & 0.0219 & 0.0548 & .1514 & 0.087 \\
\hline
\end{tabular}

\section{Dosage-response analysis}

The next step is to conduct a dose-response analysis to find the reference concentration (RfC) value of each pollutant risk agent that is being studied by the ARKL and to know the effect of the risk agent on the human body.

Table 2. RfC values in $\mathrm{SO}_{2}, \mathrm{NO}_{2}, \mathrm{NH}_{3}$ and dust compounds

\begin{tabular}{clc}
\hline \multicolumn{1}{c}{ Agent } & \multicolumn{1}{c}{ RfC value } & \multicolumn{1}{c}{ Critical Effects and References } \\
\hline Sulfur Dioxide $\left(\mathrm{SO}_{2}\right)$ & $\begin{array}{l}0.026 \\
\mathrm{mg} / \mathrm{kg} / \text { day }\end{array}$ & Respiratory disorders (EPA / NAAQS 1990) \\
\hline Nitrogen Dioxide $\left(\mathrm{NO}_{2}\right)$ & 0.02 & Respiratory disorders (EPA / NAAQS 1990) \\
\hline
\end{tabular}




\section{STRADA Jurnal Ilmiah Kesehatan}

DOI: $10.30994 /$ sjik.v9i2.350

ISSN: 2252-3847 (print); 2614-350X (online)

Vol.9 No.2 November 2020 Page.1346-1352

\begin{tabular}{lll}
\hline & $\mathrm{mg} / \mathrm{kg} /$ day & \\
\hline Ammonia $\left(\mathrm{NH}_{3}\right)$ & $\begin{array}{l}0.5 \\
\mathrm{mg} / \mathrm{kg} / \text { day }\end{array}$ & $\begin{array}{l}\text { Decreased lung function and respiratory disorders } \\
\text { (Holness et al., 1989; Rahman et al., 2007; Ballal et } \\
\text { al., 1998; Ali et al., 2001) }\end{array}$ \\
\hline Dust Particles & $\begin{array}{l}2.42 \\
\mathrm{mg} / \mathrm{kg} / \text { day }\end{array}$ & Respiratory disorders (EPA / NAAQS 1990) \\
\hline
\end{tabular}

Source: 2012 Ministry of Health Environmental Health Risk (ARKL) Guidelines

\section{Exposure Analysis}

Intake calculation is done with the default value of the US-EPA exposure factor. The data used in ARKL is secondary data from the measurement of the concentration of risk agents (SO2, NO2, NH3, and dust) on the ambient air media carried out by the BBTKLPP Surabaya air laboratory installation. The intake formula (I) used is as follows:

Intake $(\mathrm{I})=\frac{C \times R \times t E \times f E \times D t}{\text { Wb } \times \text { tavg }}$

Table 3 Value of Exposure to Air Pollution in the Industrial Center Environment in East Java

\begin{tabular}{cllll}
\hline \multirow{2}{*}{$\mathrm{C}$} & \multicolumn{4}{c}{ Parameter intake } \\
\cline { 2 - 5 } & $\mathrm{SO}_{2}$ & $\mathrm{NO}_{2}$ & $\mathrm{NH}_{3}$ & Dust \\
\hline \multicolumn{5}{c}{ Surabaya } \\
\hline Cmin & 0.00002 & 0,00017 & 0,00014 & 0,0007 \\
\hline Cmax & 0.0064 & 0.0026 & 0.01111 & 0.0170 \\
\hline \multicolumn{5}{c}{ Gresik } \\
\hline Cmin & 0,0001 & 0,0002 & 0,00052 & 0.0019 \\
\hline Cmax & 0.0025 & 0.0021 & 0.06434 & 0.0114 \\
\hline \multicolumn{5}{c}{ Sidoarjo } \\
\hline Cmin & 0,0001 & 0,0002 & 0.00149 & 0.0021 \\
\hline Cmax & 0.0018 & 0.0045 & 0.01252 & 0.0072 \\
\hline
\end{tabular}

\section{Risk Characterization}

After knowing the results of the exposure (Intake), the next stage is Risk characterization to compare the results of the analysis of exposure (intake) with a reference concentration (RfC) known as the risk number or Risk Quotient (RQ). RQ is calculated using the following formula:

$$
\mathrm{RQ}=\mathrm{I} / \mathrm{RfC}
$$

Table 4. RQ Value of Air Pollution Exposure in the Industrial Center Environment in East Java

\begin{tabular}{ccccc}
\hline \multirow{2}{*}{$\mathrm{C}$} & \multicolumn{4}{c}{ RQ Parameters } \\
\cline { 2 - 5 } & $\mathrm{SO}_{2}$ & $\mathrm{NO}_{2}$ & $\mathrm{NH}_{3}$ & Dust \\
\hline \multicolumn{5}{c}{ Surabaya } \\
\hline Cmin & 0.0010 & 0.0087 & 0,0003 & 0,0003 \\
\hline Cmax & 0.2458 & 0.1298 & 0.0222 & 0.0070 \\
\hline \multicolumn{5}{c}{ Gresik } \\
\hline Cmin & 0.0041 & 0.0079 & 0.0010 & 0,0008 \\
\hline Cmax & 0.0960 & .1075 & 0.1287 & 0.0047 \\
\hline
\end{tabular}




\section{STRADA Jurnal Ilmiah Kesehatan}

DOI: $10.30994 /$ sjik.v9i2.350

ISSN: 2252-3847 (print); 2614-350X (online)

Vol.9 No.2 November 2020 Page.1346-1352

\begin{tabular}{lllll}
\hline \multicolumn{5}{c}{ Sidoarjo } \\
\hline Cmin & 0.0045 & 0.0091 & 0.0030 & 0,0009 \\
\hline Mmmm & 0.0697 & 0.2266 & 0.0250 & 0.0030 \\
\hline
\end{tabular}

\section{Risk management}

Risk management is carried out if the results of risk characteristics show unsafe results or RQ values> 1. Risk management is carried out to prevent and minimize the health impacts caused by the environment by reducing safe concentrations and limiting the duration of exposure to safe limits.

\section{Risk communication}

Based on the results of the calculation of the Environmental Health Risk Analysis (ARKL), which has been carried out from the previous stages, it is known that the risk generated is that the value is still within safe limits.

\section{DISCUSSION}

\section{Hazard Identification}

Based on research results, the highest $\mathrm{SO}_{2}$ concentration point is in the city of Surabaya $0.0773 \mathrm{mg} / \mathrm{m}^{3}$, and the lowest is in the city of Surabaya of $0,0003 \mathrm{mg} / \mathrm{m}^{3}$. From the results of the study, it can be concluded that $\mathrm{SO} 2$ concentrations are still below the Quality Standards according to PP 41/1999 on Air Pollution Control for $\mathrm{SO}_{2}$ concentrations

Based on the results of the study, the highest $\mathrm{NO}_{2}$ concentration point was in Sidoarjo Regency $0,0003 \mathrm{mg} / \mathrm{m}^{3}$, and the lowest was in Gresik Regency with $0.0019 \mathrm{mg} /$ $\mathrm{m}^{3}$. From the results of the study, it can be concluded that $\mathrm{NO}_{2}$ concentration is still below the Quality Standards according to PP 41/1999 on Air Pollution Control for $\mathrm{NO}_{2}$ concentration.

Based on the study results, the highest $\mathrm{NH}_{3}$ concentration point was in Gresik Regency $.7781 \mathrm{mg} / \mathrm{m} 3$, and the lowest was in Surabaya City, with $0.0017 \mathrm{mg} / \mathrm{m}^{3}$. From the results of the study, it can be concluded that $\mathrm{NH}_{3}$ concentrations are still below the Quality Standards according to PP 41/1999 on Air Pollution Control for $\mathrm{NH}_{3}$ concentrations.

Based on the results of the study, the highest dust concentration point is in the city of Surabaya $.205 \mathrm{mg} / \mathrm{m}^{3}$, and the lowest was in Surabaya City with $0.009 \mathrm{mg} / \mathrm{m}^{3}$. From the results of the study, it can be concluded the dust concentration is still below the Quality Standards according to PP 41/1999 on Air Pollution Control for dust concentration.

\section{Dose-Response Analysis}

In the ARKL study, exposure to $\mathrm{SO}_{2}, \mathrm{NO}_{2}, \mathrm{NH}_{3}$, and dust gasses on workers in Surabaya, Gresik, and Sidoarjo cities can enter the human body through inhalation non-carcinogenic pathways. So the value used as a reference dose for inhalation is RfC. Each polluting agent has its response dose. This means that if the exposure value is more than $\mathrm{RfC}$, it will cause several health problems related to each pollutant's effects in exposure to $\mathrm{SO}_{2}, \mathrm{NO}_{2}, \mathrm{NH}_{3}$, and dust on the community in the cities of Surabaya, Gresik, and Sidoarjo in 2020.

\section{Exposure Analysis}

Exposure to industrial pollutants in Surabaya, Gresik, and Sidoarjo industrial centers enter the body through the inhalation pathway as it passes through the respiratory system. Air pollutants are non-carcinogenic pollutants. The calculation of this exposure 


\section{STRADA Jurnal Ilmiah Kesehatan}

DOI: $10.30994 /$ sjik.v9i2.350

ISSN: 2252-3847 (print); 2614-350X (online)

Vol.9 No.2 November 2020 Page.1346-1352

analysis will produce a minimum and maximum intake value to find the value of the level of health risk caused by exposure to pollutant agents.

The highest contamination agent exposure in the city of Surabaya was dust exposure with a Cmax value of $0.0170 \mathrm{mg} / \mathrm{kgxday}$. The lowest exposure was $\mathrm{SO}_{2}$, with an amount of $0.00002 \mathrm{mg} / \mathrm{kgxday}$. At the same time, the industrial center polluting agent in Gresik Regency is the highest $\mathrm{NH}_{3}$ exposure with a value of $0.06434 \mathrm{mg} / \mathrm{kgxday}$ and the lowest exposure to $\mathrm{SO}_{2}$ with an amount of $0.0001 \mathrm{mg} / \mathrm{kgxday}$. The most top polluting agent of industrial centers in the Sidoarjo region is $\mathrm{NH}_{3}$ exposure with a value of 0.01252 $\mathrm{mg} / \mathrm{kg} \mathrm{x}$ day and lowest $\mathrm{SO}_{2}$ exposure of $0,0001 \mathrm{mg} / \mathrm{kg}$ x day.

\section{Risk Characterization}

The characteristics of health risks are stated as RQ (Risk Quotient) or the level of risk for non-carcinogenic effects. RQ value indicates the level of health risk due to exposure to pollutant agents.

The RQ value is calculated by comparing the intake or concentration of risk agents that enter the human body per specific bodyweight each day with the RfD (Reference Dose) values obtained based on literature in the Integrated Risk Information System (IRIS) database.

The highest level of risk (RQ) in Surabaya is $\mathrm{SO}_{2}$ with $\mathrm{RQ}$ values 0.2458 , and the lowest is $\mathrm{NH}_{3}$ and dust with RQ values 0,0003 . Whereas the industrial center in Gresik Regency has the highest RQ value of $\mathrm{NH}_{3} 0.1287$ and the smallest is as big as dust 0,0008 , The highest RQ value of industrial centers in the Sidoarjo region is $\mathrm{NO}_{2}$ exposure with value 0,2266 , and the lowest RQ is dust with an amount of 0,0009 .

Based on Table 4 shows that the minimum RQ value and the maximum RQ of each pollutant agent are $<1$ which means that in adults such as workers in risk groups with an estimated body weight of $55 \mathrm{~kg}$ for 250 days/year for the next 30 years it is said to be safe when working at the industrial centers of the City of Surabaya, Gresik and Sidoarjo with a concentration value of air pollutant agents no more than those available.

\section{CONCLUSION}

1. Pollutant Agents are at risk of air parameters for industrial center workers in Surabaya, Gresik, and Sidoarjo whose SO2, NO2, NH3, and dust gases in 2020 are still below the established quality standards.

2. The response dose of pollutant agents at risk of air pollution for workers in the cities of Surabaya, Gresik, and Sidoarjo in 2020 with exposure routes through inhalation, therefore, uses the RfC value (reference concentration)

3. The value of air pollutants in Surabaya, Gresik, and Sidoarjo, namely SO2, NO2, NH3, and dust gases, is adjusted to the default value of Indonesian society's anthropometry.

4. The calculation of the risk characteristics (RQ) of Surabaya, Gresik, and Sidoarjo cities with $\mathrm{SO} 2, \mathrm{NO} 2, \mathrm{NH} 3$, and dust gasses in 2020 shows the RQ value of the entire sample point is $<1$. This means that the exposure of $\mathrm{SO} 2, \mathrm{NO} 2, \mathrm{NH} 3$, and dust gasses inhalation by workers, i.e., adults weighing $55 \mathrm{~kg}$, is considered safe for the frequency of exposure for up to 250 days/year to 30 years.

5. Risk management related to exposure to pollutant agents in Surabaya, Gresik, and Sidoarjo cities needs to be done to maintain and maintain air water quality in Surabaya, Gresik, and Sidoarjo City companies, as well as to conduct periodic checks and control parameters of pollutants that exceed the standards quality. 


\section{STRADA Jurnal Ilmiah Kesehatan}

DOI: $10.30994 /$ sjik.v9i2.350

ISSN: 2252-3847 (print); 2614-350X (online)

Vol.9 No.2 November 2020 Page.1346-1352

6. Communication of the risk of exposure to air pollution in the City of Surabaya, Gresik, and Sidoarjo by involving parties, DLH, the Department of Health, and the Regional Government of Pasuruan Regency in being responsible for air quality starting from the source of air pollution to the general public.

\section{REFERENCE}

ATSDR, (2004). Toxicological Profile of Ammonia.

Direktorat Jenderal PP dan PL, (2012). Pedoman Analisis Risiko Kesehatan Lingkungan.

Darmayasa, I Gede Oka. (2013). Dampak NOx Terhadap Kesehatan. Jurnal Ilmiah Kurva Teknik.

EPA, (2018). Air Topics. https://www.epa.gov/environmental-topics/air-topics. Diakses pada 25 Maret 2020

Mukono, (2006). Prinsip Dasar Kesehaan Lingkungan Edisi Kedua. Airlangga University Press, Surabaya.

Mukono, (2002). Epidemiologi Lingkungan. Airlangga University Press, Surabaya.

Pemerintah Republik Indonesia, (1999). Peraturan Pemerintah Republik Indonesia Nomor 41 Tahun 1999 Tentang Pengendalian Pencemaran Udara. Pemerintah Republik Indonesia, Jakarta 